\title{
DETEKSI TEMPERATUR PERMUKAAN TANAH DI RUAS JALAN ARTERY DENGAN CITRA LANDSAT 8 DAN KORELASINYA DENGAN ARUS DAN KEPADATAN LALU LINTAS
}

\author{
Hendrata Wibisana, Siti Zainab, Fithrie Estikhamah \\ Jurusan Teknik Sipil, UPN Veteran Jawa Timur \\ Email : hendrata2008@gmail.com
}

\begin{abstract}
ABSTRAK
Jalan raya merupakan prasarana yang dibangun sebagai tempat bagi manusia dan barang untuk melakukan perpindahan dari satu tempat ke tempat yang lain. Jalan arteri merupakan jalan dengan jumlah volume lalu lintas yang tinggi, sehingga dengan jumlah volume yang tinggi maka kepadatan per satuan kilometer menjadi besar dan rawan untuk terjadinya polusi gas buang kendaraan yang tersebar sepanjang ruas jalan tersebut. Terjadinya polusi gas buang disamping dari panas mesin kendaraan bermotor akan membuat udara disekitar menjadi tidak stabil. Ada kecenderungan suhu permukaan tanah meningkat akibat peningkatan jumlah kendaraan. Dengan bantuan teknologi penginderaan jauh, hendak dicari hubungan antara nilai temperatur permukaan tanah yang diperoleh dari ekstrak nilai radians citra satelit dengan volume lalu lintas serta kepadatan kendaraan yang terjadi. Dan dari hasil perhitungan dengan mengambil nilai volume kendaraan dan kepadatan kendaraan sebagai variabel independent dan nilai temperatur permukaan tanah sebagai variabel dependent maka diperoleh algoritma hubungan antara karakteristik suatu ruas jalan dengan temperatur dari citra satelit.
\end{abstract}

Kata kunci : Volume lalu lintas, kepadatan kendaraan, suhu permukaan tanah, citra satelit

\begin{abstract}
The highway is an infrastructure built as a place for people and goods to move from one place to another. Arterial road is a road with a high volume of traffic, so with a high amount of volume the density per unit kilometer becomes large and prone to the occurrence of exhaust gas pollution vehicles scattered along the road. The occurrence of exhaust gas pollution in addition to the engine heat of the vehicle will make the air around to become unstable. There is a tendency of rising ground temperatures due to an increase in the number of vehicles. With the help of remote sensing technology, the goal of this research is to find a relationship between the surface temperature of the soil obtained from the extract of the satellite image radians value with the volume of traffic and the density of the vehicle. And from the calculation by taking the value of vehicle volume and vehicle density as independent variables and the value of surface temperature as the dependent variable, the algorithm obtained the relationship between the characteristics of a road segment with the temperature of the satellite image.
\end{abstract}

Keywords : Traffic volume, density of road, land surface temperature, satellite images

\section{PENDAHULUAN}

Jalan raya dibangun dalam upaya untuk menyediakan prasarana transportasi yang nyaman dan aman untuk bepergian dari satu tempat ke tempat yang lainnya. Sebagai jalan arteri atau jalan utama yang memiliki jumlah volume lalu lintas 
yang tinggi maka jalan raya arteri memiliki kecenderungan kepadatan kendaraan yang tinggi dan kecepatan kendaraan yang melambat. Tingkat populasi kendaraan yang tinggi dalam ruas kilometer jalan utama sering sulit dalam proses pemantauan dikarenakan belum adanya teknologi yang dikembangkan untuk memantau dalam area yang luas. Teknologi penginderaan jauh merupakan salah satu teknologi yang memiliki kemampuan untuk mengcover area dengan luasan yang tinggi serta tingkat keakuratan yang tinggi dalam penyampaian data. Citra satelit yang diperoleh dari pesawat ruang angkasa dapat memberikan gambaran tentang kondisi alam dengan cakupan area yang luas dan dengan banyaknya wahana satelit yang terdapat di ruang angkasa dan dengan adanya sensor yang sangat peka terhadap refleksi dari pancaran sinar matahari yang dipantulkan dari permukaan bumi maka analisa mengenai fenomena perubahan alam yang terjadi didalamnya dapat lebih mudah untuk diamati dan dapat menjangkau daerah yang rawan atau sulit dilakukan pengukuran secara manual (Tang H., 2008; Wan Z., 1996; Yang Y., 2017). Salah satu teknologi yang sedang berkembang dari citra satelit saat ini adalah teknologi penangkapan temperatur permukaan tanah, dimana dari nilai digital number yang setelah dikonversi ke dalam nilai radians dapat memberikan gambaran temperature yang terdapat pada permukaan bumi ( $\mathrm{Li}$ Z.L.,2013; Lin Y.,2006; Sandholt, 2002; Sandholt, 2009).

\section{TUJUAN PENELITIAN}

Tujuan dari penelitian ini adalah untuk memberikan peta sebaran temperature permukaan tanah di beberapa ruas jalan arteri yang terdapat di kota Surabaya dan kemudian mencari hubungan antara nilai temperatur ini dengan nilai kepadatan jalan yang terjadi, apakah dengan nilai kepadatan kendaraan yang tinggi akan menaikkan nilai dari permukaan tanah yang berakibat suhu ruas jalan menjadi semakin panas atau sebaliknya.

\section{METODE PENELITIAN}

Penelitian ini dibagi dalam 2 bagian pekerjaan, dimana untuk tahap pertama dilakukan pengukuran kondisi karakteristik lalu lintas di masing-masing ruas jalan yang dipilih. Pengukuran meliputi pengukuran kecepatan kendaraan yang melintas dalam 
satuan meter per detik yang dikonversi ke dalam $\mathrm{km} / \mathrm{jam}$, volume lalu lintas dalam satuan kendaraan per jam yang nantinya dikonversi ke dalam smp/jam. Pada tiap titik pengamatan kecepatan kendaraan dan volume lalu lintas diukur pula koordinat lintang dan bujur sebagai acuan untuk melanjutkan ke pengukuran tahap 2 berupa pengukuran temperatur permukaan tanah dan dapat dilihat pada Tabel 1 .

Tabel 1. Penentuan koordinat geografis titik sampel penelitian

\begin{tabular}{|l|l|l|l|}
\hline No & Lintang & Bujur & Ruas Jalan \\
\hline 1 & $7^{\circ} 17^{\prime} 2.62 " \mathrm{~S}$ & $112^{\circ} 40^{\prime} 11.38^{\prime \prime} \mathrm{T}$ & Raya Lontar \\
\hline 2 & $7^{\circ} 17^{\prime} 0.82 " \mathrm{~S}$ & $112^{\circ} 41^{\prime} 29.38^{\prime \prime} \mathrm{T}$ & Raya HR.Mohammad \\
\hline 3 & $7^{\circ} 16^{\prime} 53.51 " \mathrm{~S}$ & $112^{\circ} 42^{\prime} 29.96^{\prime \prime} \mathrm{T}$ & Dukuh Kupang Barat \\
\hline 4 & $7^{\circ} 15^{\prime} 38.87^{\prime \prime} \mathrm{S}$ & $112^{\circ} 42^{\prime} 30.26^{\prime \prime} \mathrm{T}$ & Banyu Urip \\
\hline 5 & $7^{\circ} 16^{\prime} 46.85^{\prime \prime} \mathrm{S}$ & $112^{\circ} 43^{\prime} 51.45^{\prime \prime} \mathrm{T}$ & Raya Diponegoro \\
\hline 6 & $7^{\circ} 17^{\prime} 6.32 " \mathrm{~S}$ & $112^{\circ} 44^{\prime} 23.16^{\prime \prime} \mathrm{T}$ & Raya Darmo \\
\hline 7 & $7^{\circ} 17^{\prime} 6.98 " \mathrm{~S}$ & $112^{\circ} 42^{\prime} 54.00^{\prime \prime} \mathrm{T}$ & Raya Dukuh Kupang \\
\hline 8 & $7^{\circ} 17^{\prime} 28.74 " \mathrm{~S}$ & $112^{\circ} 43^{\prime} 12.04^{\prime \prime T}$ & Mayjen Sungkono \\
\hline 9 & $7^{\circ} 17^{\prime} 50.78^{\prime \prime} \mathrm{S}$ & $112^{\circ} 44^{\prime} 0.99^{\prime \prime} \mathrm{T}$ & Joyoboyo \\
\hline 10 & $7^{\circ} 18^{\prime} 40.12 " \mathrm{~S}$ & $112^{\circ} 41^{\prime} 27.10^{\prime \prime T}$ & Menganti Karangan \\
\hline 11 & $7^{\circ} 19^{\prime} 8.69 " \mathrm{~S}$ & $112^{\circ} 42^{\prime} 35.03^{\prime \prime T}$ & Raya Mastrip \\
\hline 12 & $7^{\circ} 18^{\prime} 52.17^{\prime \prime} \mathrm{S}$ & $112^{\circ} 44^{\prime} 1.92^{\prime \prime T}$ & Raya Wonokromo \\
\hline
\end{tabular}

Pada bagian 2 dilakukan pengukuran temperatur permukaan tanah dengan memanfaatkan citra satelit Landsat 8 yang memiliki resolusi spasial 100 x 100 meter masing-masing untuk kanal 10 dan kanal 11 dari kanal yang ada pada citra satelit Landsat Pengukuran nilai digital number sebelum dikonversi menjadi radians dilakukan pada koordinat yang sudah ditentukan saat pengambilan data arus lalu lintas dan kecepatan kendaraan untuk masing-masing sampel ruas jalan, dan gambaran tersebut dapat dilihat pada Gambar 1. 


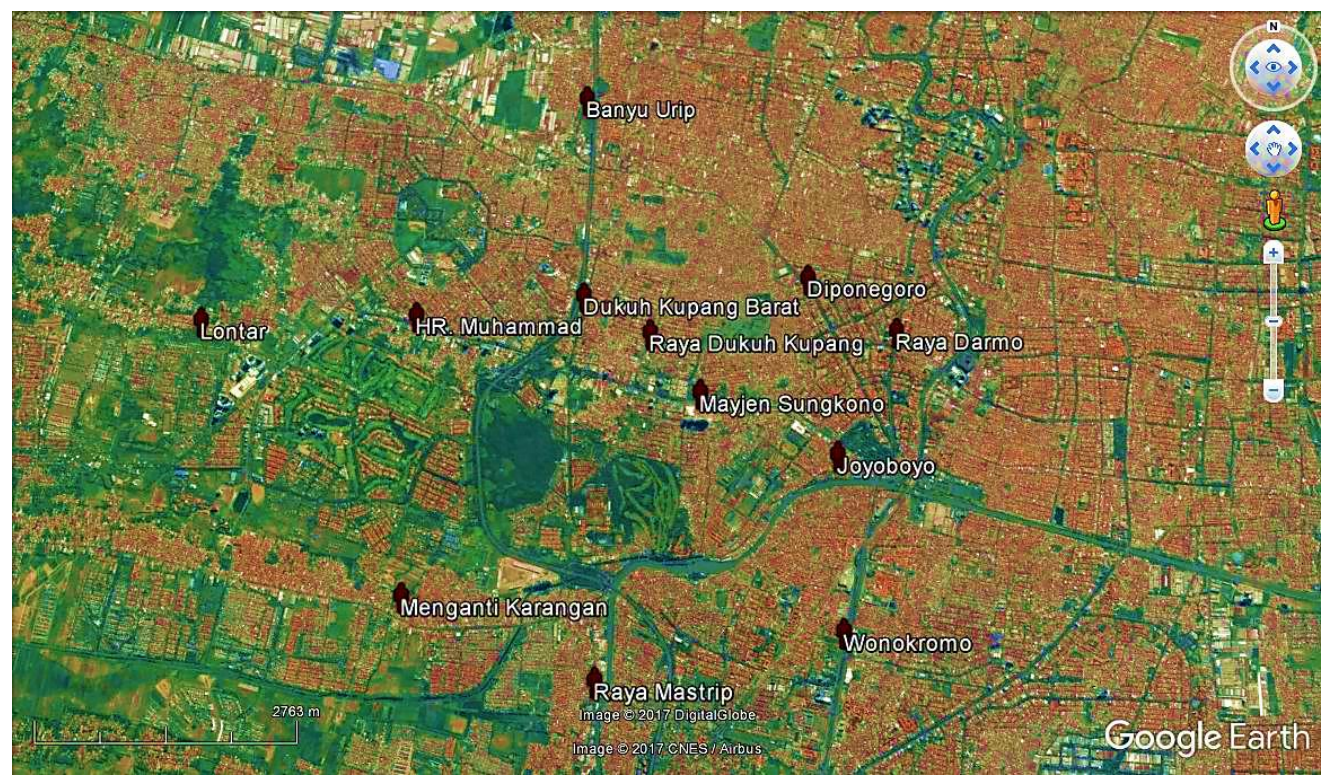

Gambar 1. Peta lokasi titik pengambilan data temperatur permukaan tanah dan data karakteristik jalan

Setelah data koordinat sudah ditetapkan maka dilakukan perhitungan nilai suhu permukaan tanah dengan cara mengekstrak nilai-nilai surface reflektan dari citra satelit Landsat 8. Untuk keoperluan tersebut maka dilakukan download citra satelit untuk akuisisi pada bulan April 2017 dan hasilnya diperlihatkan pada Gambar 2, masih dalam bentuk aslinya hasil perekaman sebelum dilakukan proses pemotongan citra sesuai dengan area yang diinginkan.

\section{HASIL DAN PEMBAHASAN}

Hasil dari pemotongan citra setelah dilakukan proses rektifikasi dimana proses ini dilakukan untuk merefresh koordinat pada citra akibat pemotongan sehingga nantinya diperoleh koordinat yang sama dengan citra aslinya sebelum dipotong. Gambar 3 memperlihatkan citra suhu permukaan tanah sesudah proses reftifikasi. 




Gambar 2. Citra satelit Landsat TIRS hasil perekaman sebelum di cropping sesuai area penelitian

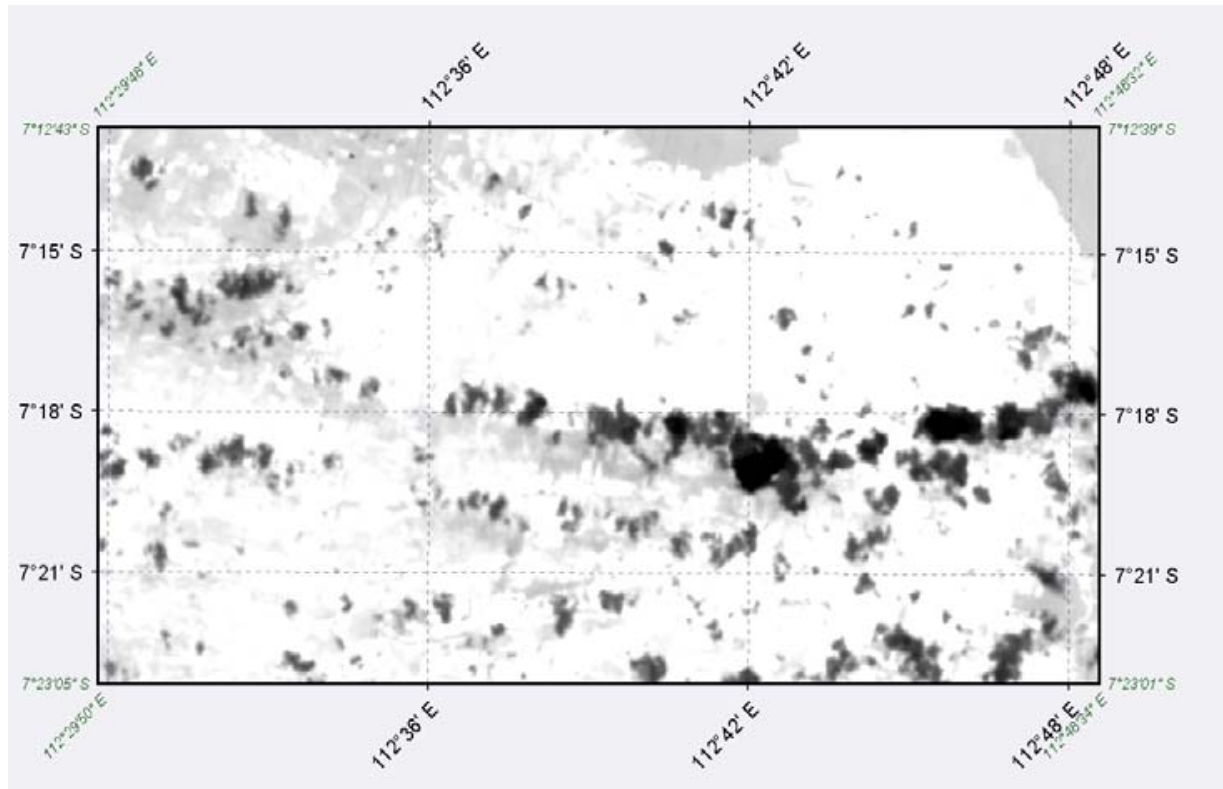

Gambar 3. Citra Landsat 8 hasil pemotongan sesuai area penelitian 


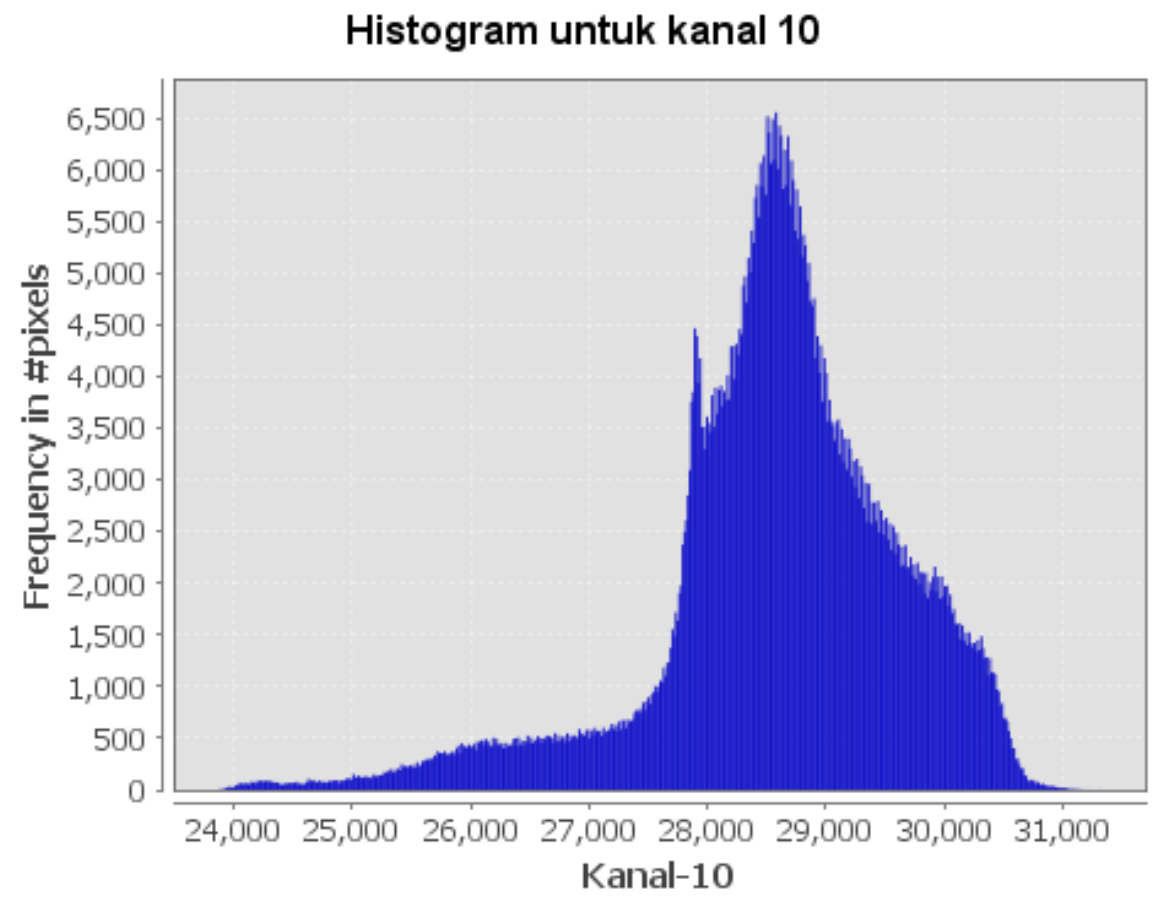

Gambar 4. Histogram dari nilai suhu permukaan tanah citra satelit Landsat 8

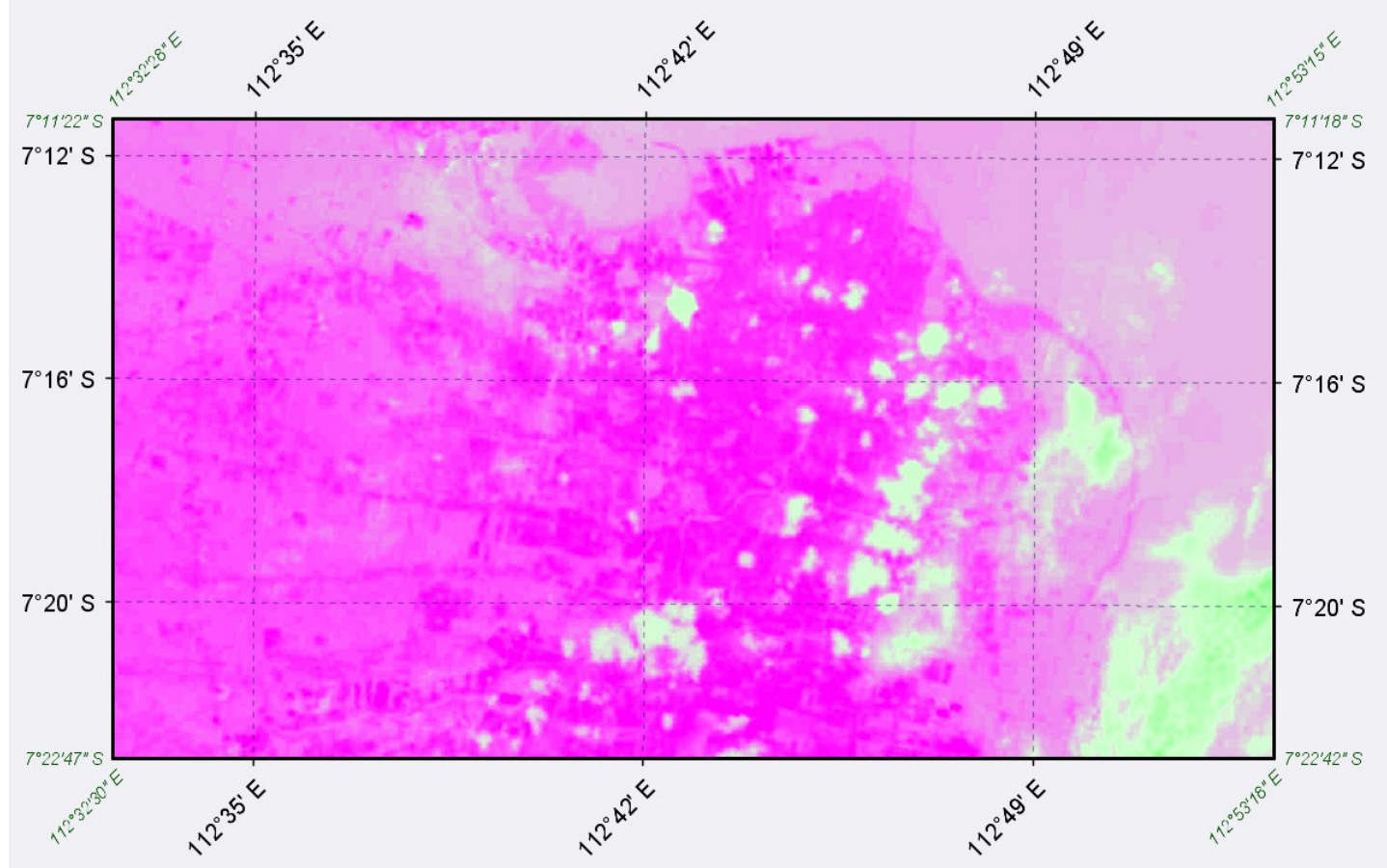

Gambar 5. Tampilan pseudocolor dari Citra satelit Landsat 8 pada area penelitian 
Untuk nilai histogram dari suhu permukaan tanah diperlihatkan pada Gambar 4., dimana dengan histogram ini memperlihatkan bahwa akumulasi suhu permukaan tanah yang memiliki frekuensi pixel terbanyak ada pada nilai $29^{\circ} \mathrm{C}$ dengan rentang yang terbesar antara suhu $28^{\circ} \mathrm{C}$ hingga $31^{\circ} \mathrm{C}$, hal ini menunjukkan bahwa pada daerah tersebut nilai suhu berkisar pada interval tersebut atau dapat dikatakan suhu pada beberapa ruas jalan yang terpilih nilainya berkisar pada rentang $28^{\circ} \mathrm{C}$ hingga $31^{\circ} \mathrm{C}$.

Untuk mendapatkan nilai suhu pada koordinat di ruas jalan yang terpilih dilakukan ekstraksi nilai pada citra satelit dan tahap pertama diperoleh nilai digital number dari citra dan nilai-nilai ini diperlihatkan pada Tabel 2.

Tabel 2. Sebaran nilai suhu dalam bentuk digital number

\begin{tabular}{ccc}
\hline Lon & Lat & band_1 \\
\hline 112,72323 & $-7,25532$ & 30079.0 \\
112,69230 & $-7,26574$ & 30202.0 \\
112,68313 & $-7,28287$ & 29774.0 \\
112,73174 & $-7,27861$ & 29869.0 \\
112,73017 & $-7,29435$ & 29928.0 \\
112,75617 & $-7,27391$ & 29684.0 \\
112,75454 & $-7,27364$ & 29577.0 \\
112,74963 & $-7,26987$ & 28522.0 \\
112,74590 & $-7,28751$ & 29154.0 \\
112,68949 & $-7,31295$ & 27137.0 \\
112,67860 & $-7,30892$ & 25320.0 \\
112,67017 & $-7,30706$ & 28059.0 \\
\hline
\end{tabular}

Hasil perhitungan nilai reflektan atau brightness temperature dilakukan dengan rumusan :

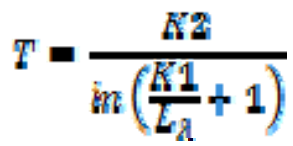

Dimana:

$\mathrm{T}=$ temperatur dari citra satelit dalam satuan Kelvin

K2 = konstanta kalibrasi yang diambil dari metadata Landsat

$\mathrm{K} 1=$ kosntanta kalibrasi yang diambil dari metadata Landsat

$\mathrm{L}=$ spektral radians dalam satuan watts $/($ meter square*ster* $\mu \mathrm{m})$ 
Untuk nilai metadata dari citra satelit Landsat diberikan pada Tabel 4 guna keperluan perhitungan suhu permukaan tanah.

Hasil dari perhitungan nilai digital number ke dalam nilai suhu citra satelit yang didapatkan diperlihatkan pada Tabel 3., dimana pada tabel tersebut juga disertakan hasil dari perhitungan lapangan untuk nilai kecepatan kendaraan dan volume lalu lintas.

Tabel 3. Data perhitungan lalu lintas dan suhu permukaan tanah

\begin{tabular}{ccccc}
\hline No & $\mathrm{S}(\mathrm{km} / \mathrm{jam})$ & $\mathrm{V}(\mathrm{smp} / \mathrm{jam})$ & $\mathrm{D}(\mathrm{smp} / \mathrm{km})$ & $\mathrm{Suhu}$ Oc \\
\hline 1 & 32,4 & 5953 & 183,735 & 30,695 \\
2 & 28,7 & 6451 & 224,774 & 30,973 \\
3 & 32,1 & 2688 & 83,738 & 30,000 \\
4 & 33,7 & 3876 & 115,015 & 30,217 \\
5 & 29,5 & 4729 & 160,305 & 30,351 \\
6 & 32,6 & 3048 & 93,497 & 29,794 \\
7 & 35,1 & 2856 & 81,368 & 29,549 \\
8 & 32,8 & 2461 & 75,030 & 27,107 \\
9 & 29,6 & 3147 & 106,318 & 28,576 \\
10 & 33,5 & 2559 & 76,388 & 23,823 \\
11 & 34,8 & 2681 & 77,040 & 19,369 \\
12 & 37,2 & 2784 & 74,839 & 26,019 \\
\hline
\end{tabular}

Berdasarkan nilai yang ada pada Tabel 3, maka dapat disusun algoritma penginderaan jauh untuk mendapatkan korelasi hubungan antara suhu permukaan tanah dengan nilai volume lalu lintas dan kerapatan kendaraan per kilometer. Penggambaran dari masing-masing algoritma untuk Kepadatan arus lalu lintas diperlihatkan pada Gambar 6. hingga Gambar 11.

Tabel 4. Metadata Landsat 8 untuk konversi suhu permukaan tanah

\begin{tabular}{cc}
\hline LANDSAT_SCENE_ID & LC81190652015142LGN00 \\
\hline FILE_DATE & 2017-05-22T12:50:32Z \\
MAP PROJECTION & UTM ; WGS 84 ; UTM ZONE :49 \\
FILE_NAME_BAND_10 & LC81190652017145LGN00_B10.TIF \\
FILE_NAME_BAND_11 & LC81190652017145LGN00_B11.TIF \\
RADIANCE_MULT_BAND_10 & $3.3420 \mathrm{E}-04$ \\
RADIANCE_MULT_BAND_11 & $3.3420 \mathrm{E}-04$ \\
RADIANCE_ADD_BAND_10 & 0.10000 \\
RADIANCE_ADD_BAND_11 & 0.10000 \\
K1_CONSTANT_BAND_10 & 774.8853 \\
K1_CONSTANT_BAND_11 & 480.8883 \\
K2_CONSTANT_BAND_10 & 1321.0789 \\
\hline
\end{tabular}

Deteksi Temperatur Permukaan Tanah Di Ruas Jalan Artery Dengan Citra Landsat 8 Dan 


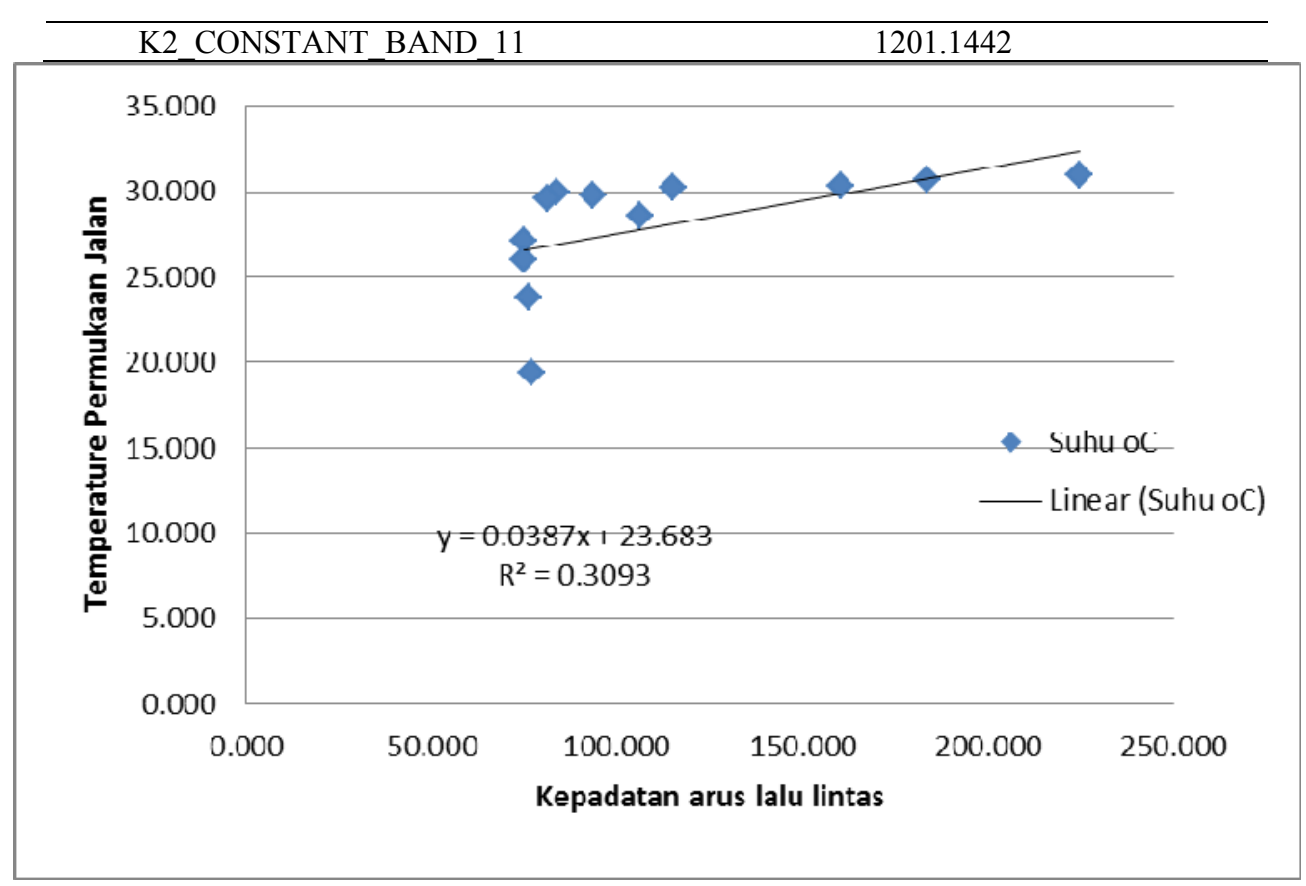

Gambar 6. Algoritma model Linier suhu permukaan tanah

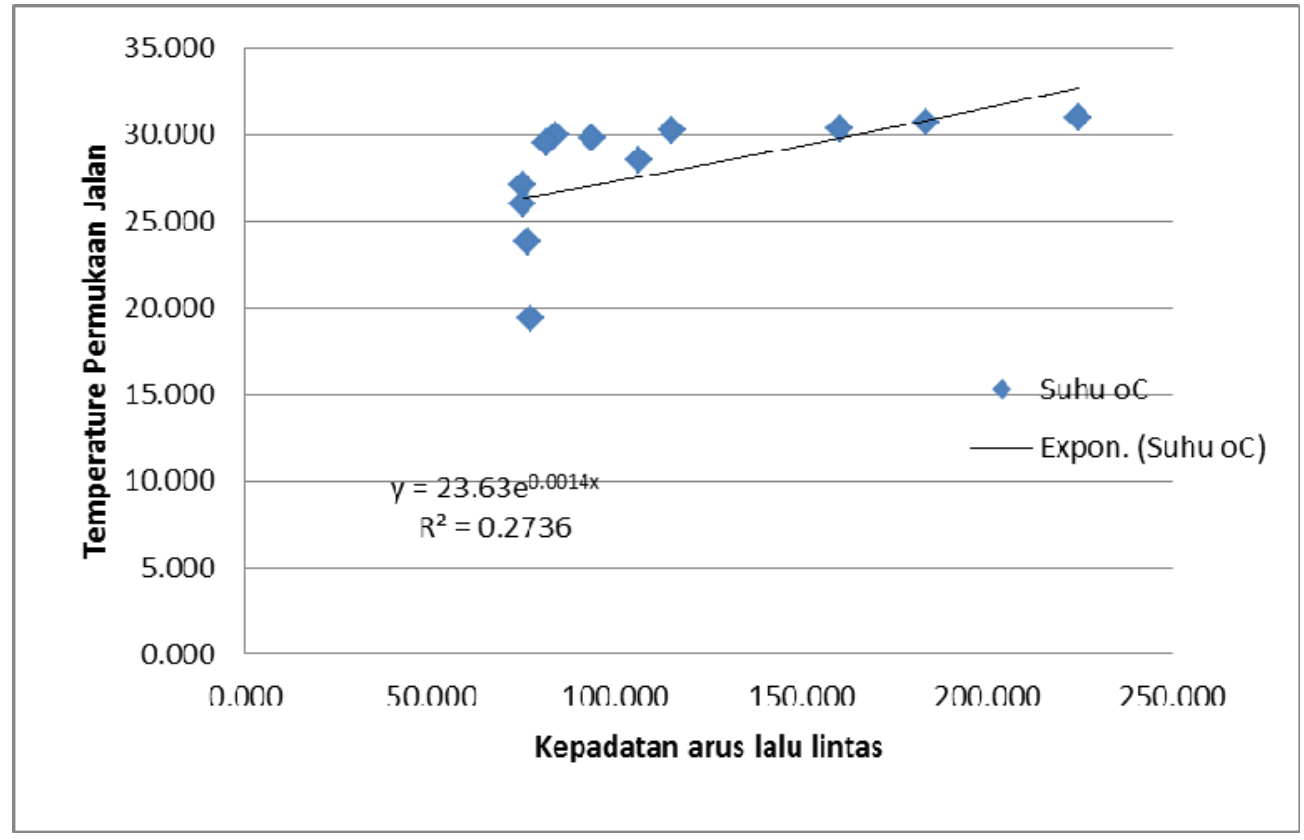

Gambar 7. Algoritma model eksponen suhu permukaan tanah 




Gambar 8. Algoritma model logaritmik suhu permukaan tanah

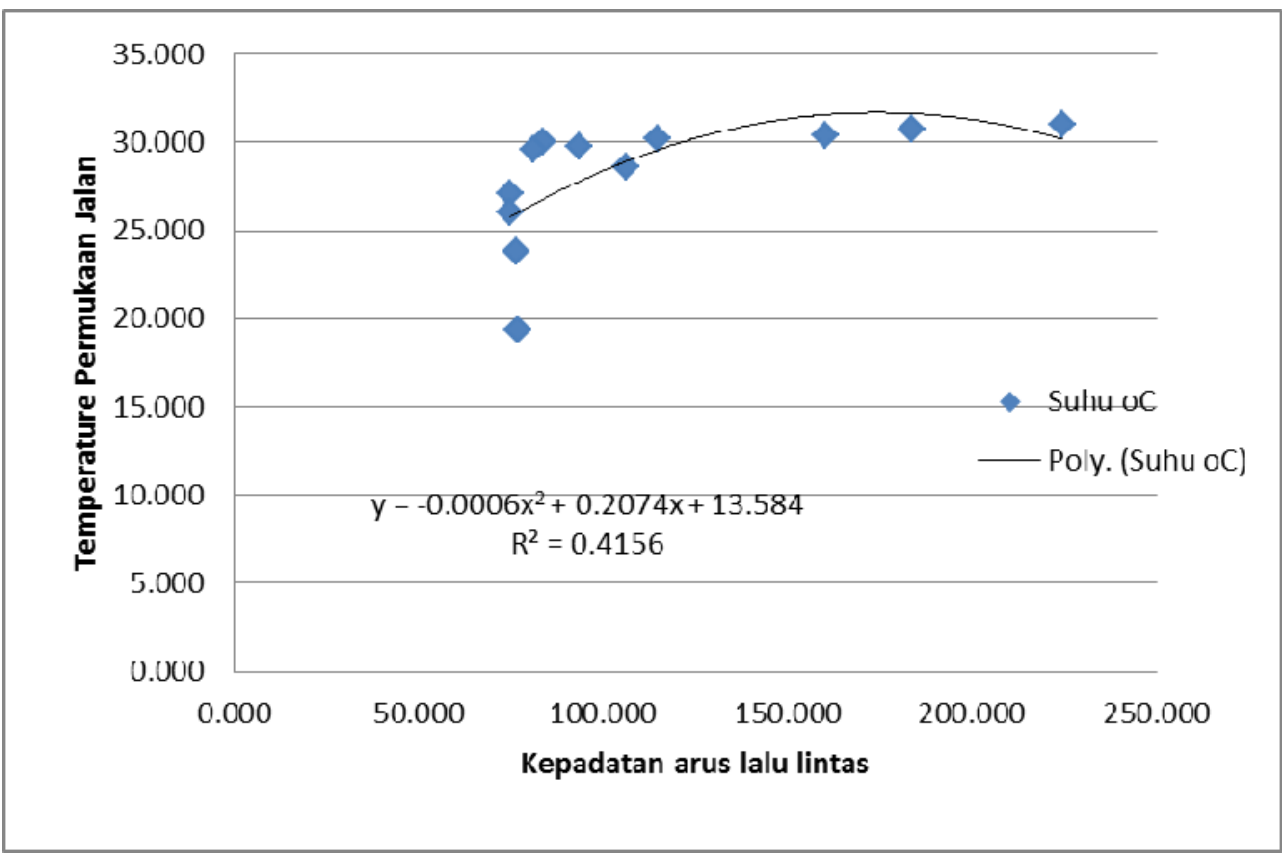

Gambar 9. Algoritma model polinom kuadratik suhu permukaan tanah 




Gambar 10. Algoritma model polinom kubik suhu permukaan tanah

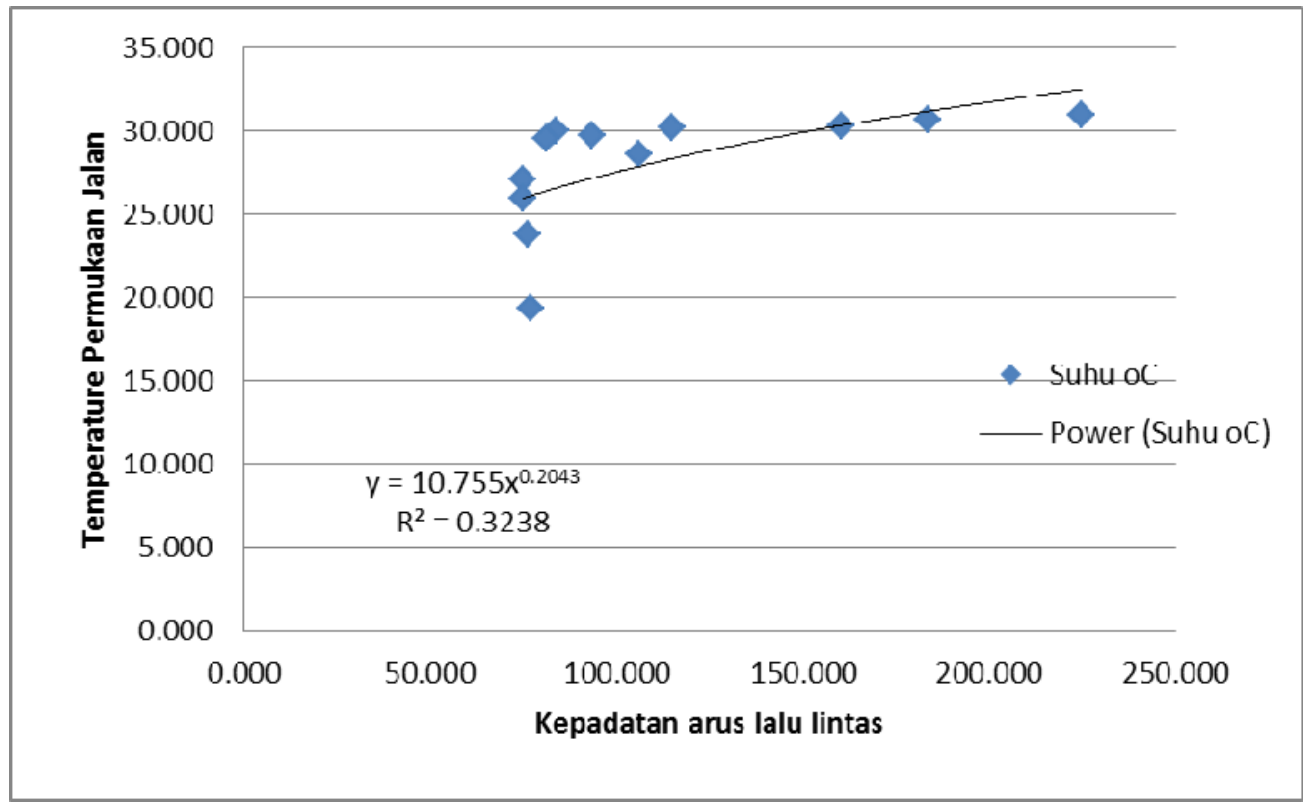

Gambar 11. Algoritma model power suhu permukaan tanah

Penggambaran dari masing-masing algoritma untuk Volume lalu lintas diperlihatkan pada Gambar 12. hingga Gambar 17. 


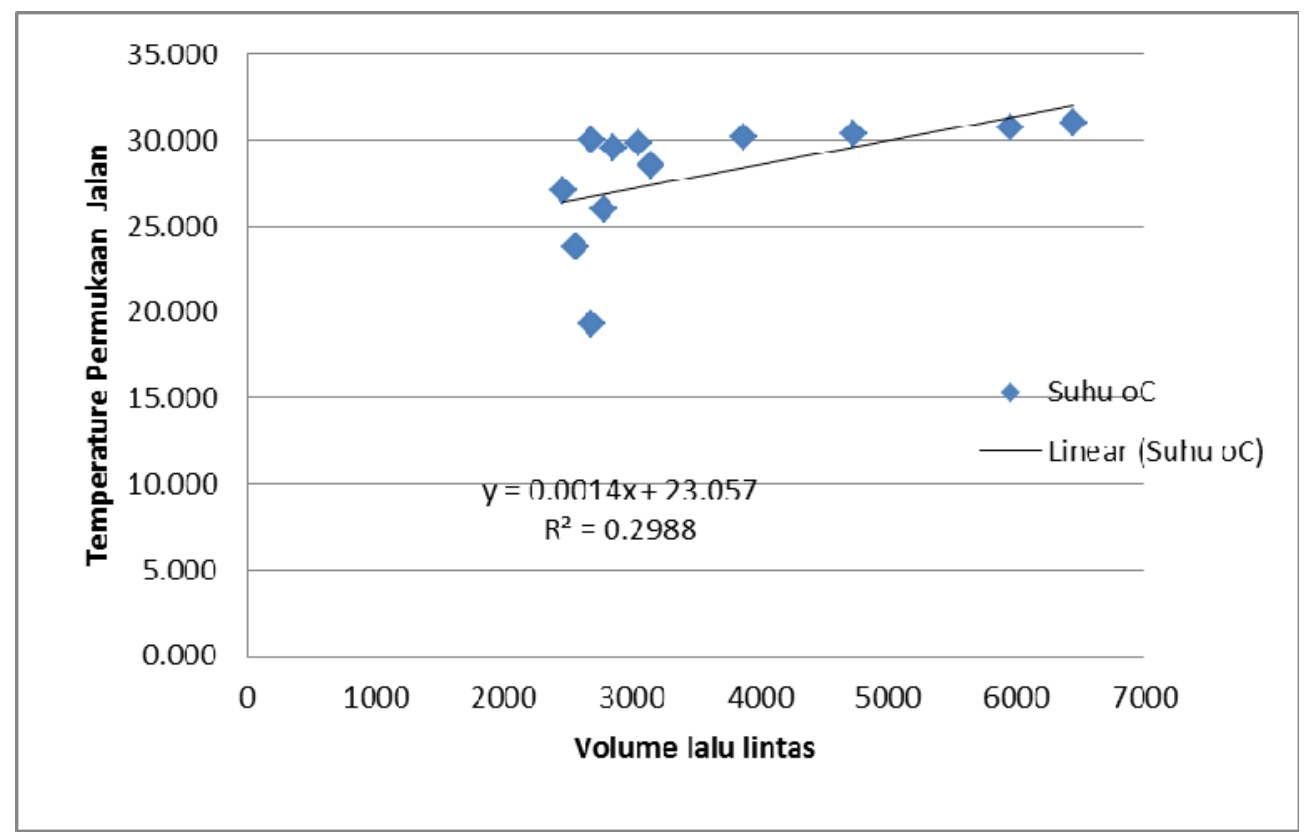

Gambar 12. Algoritma model linier volume lalu lintas

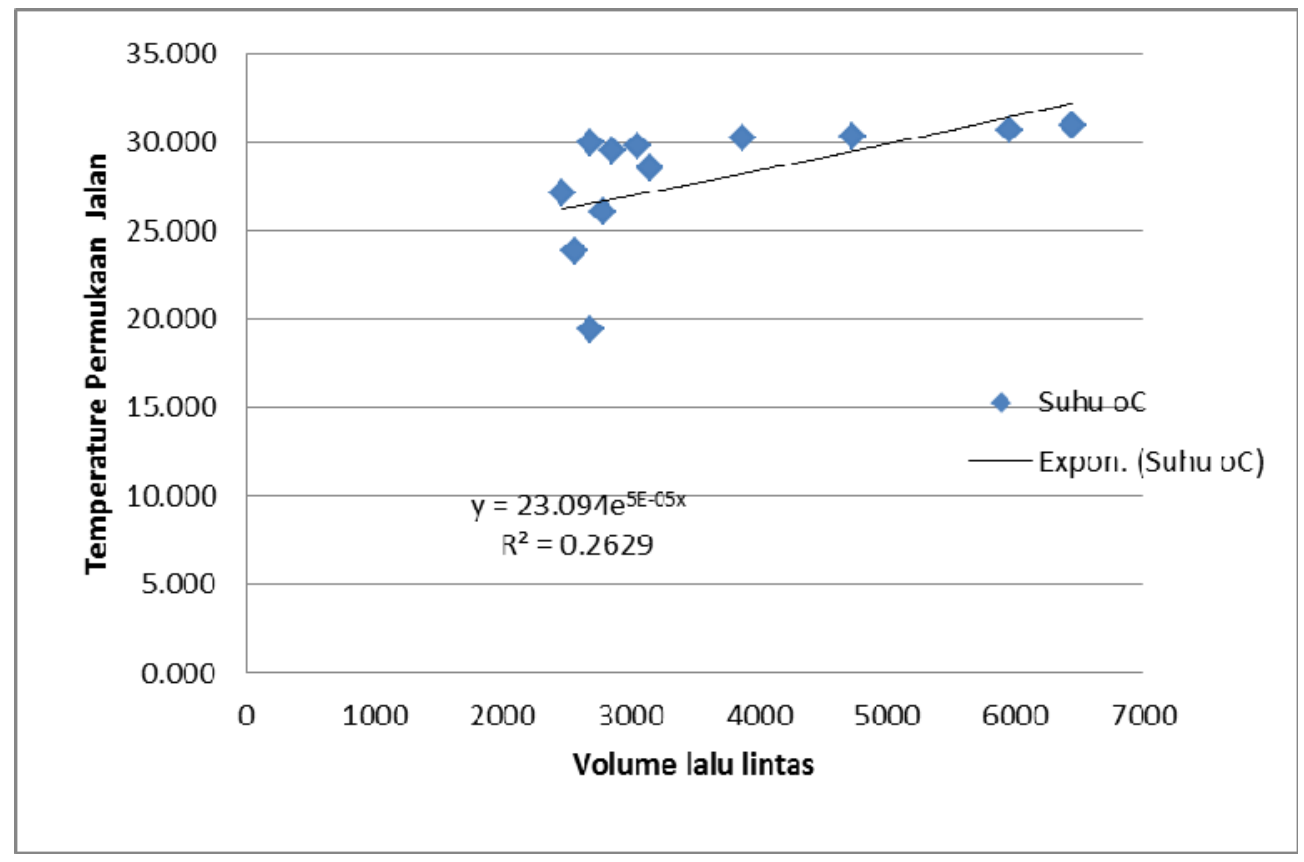

Gambar 13. Algoritma model eksponen volume lalu lintas 


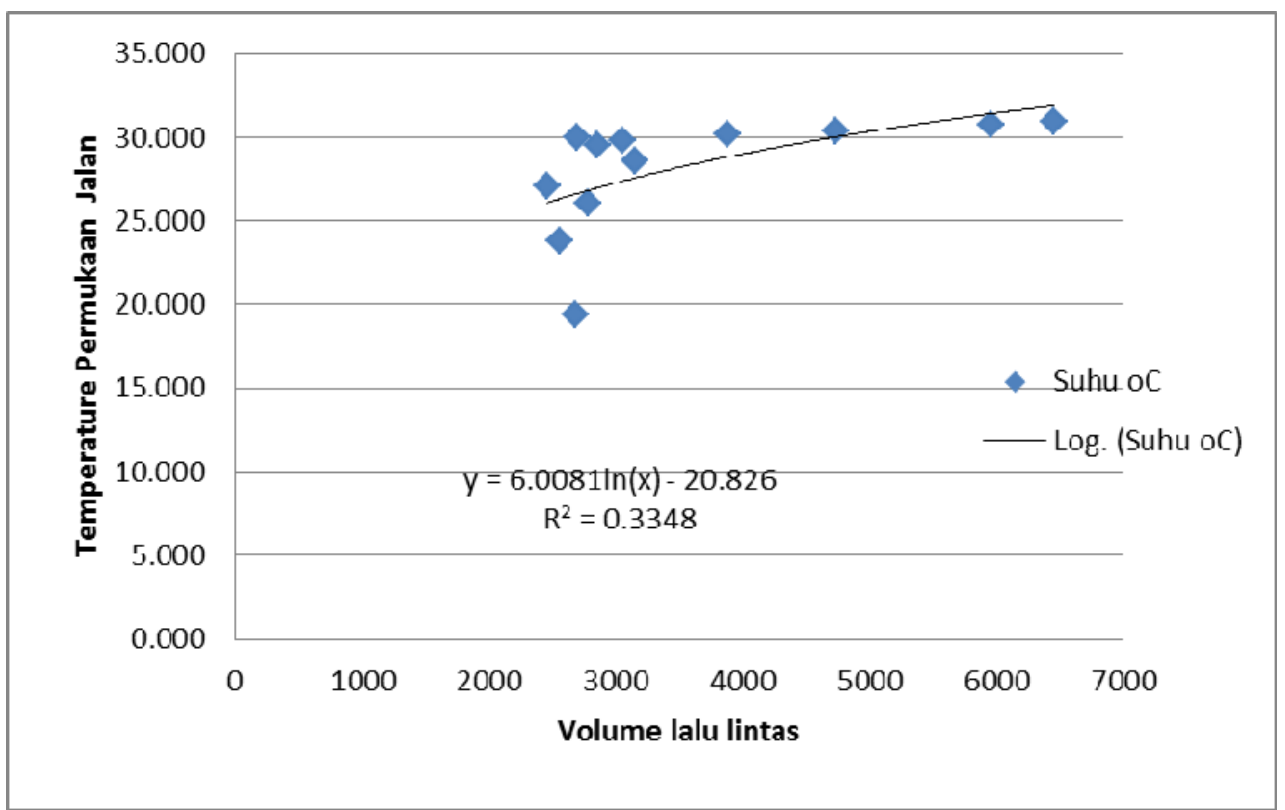

Gambar 14. Algoritma model logaritmik volume lalu lintas

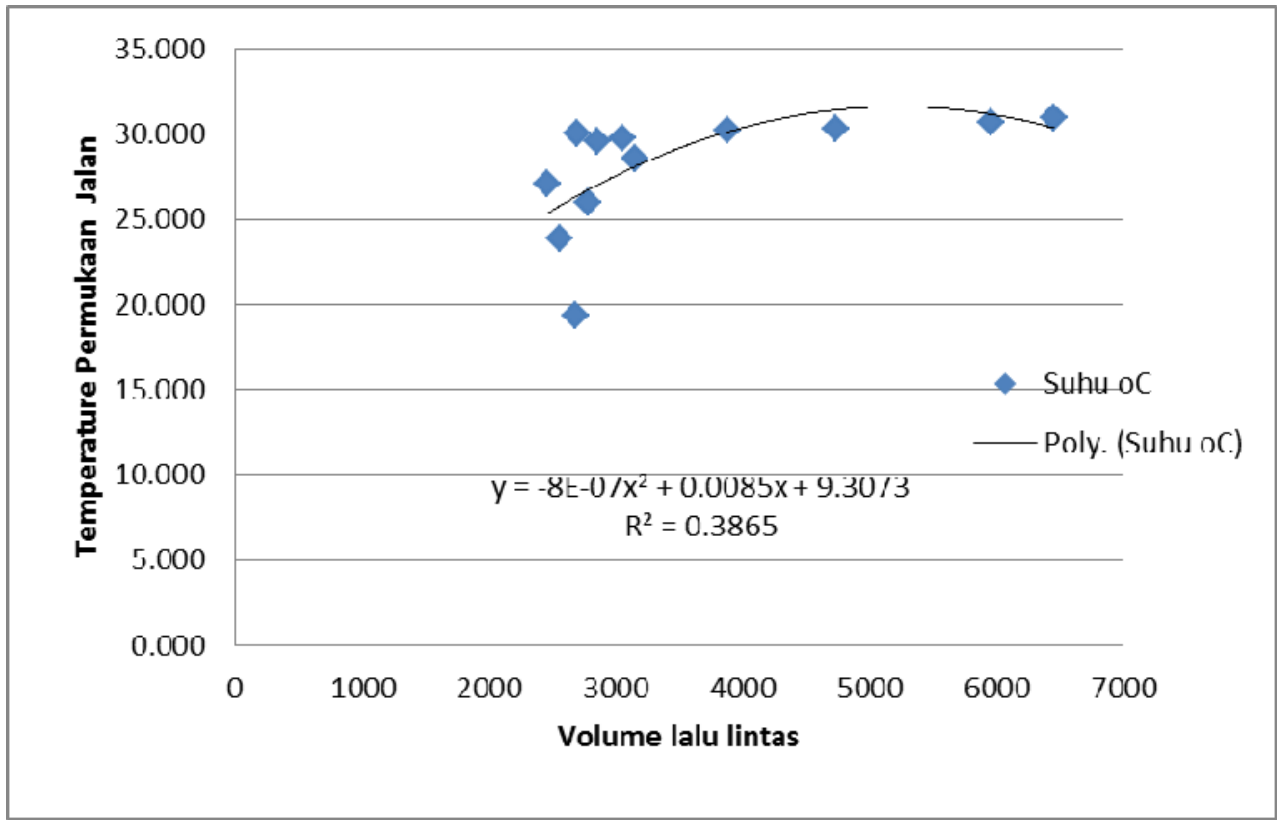

Gambar 15. Algoritma model polinom kuadratik volume lalu lintas 


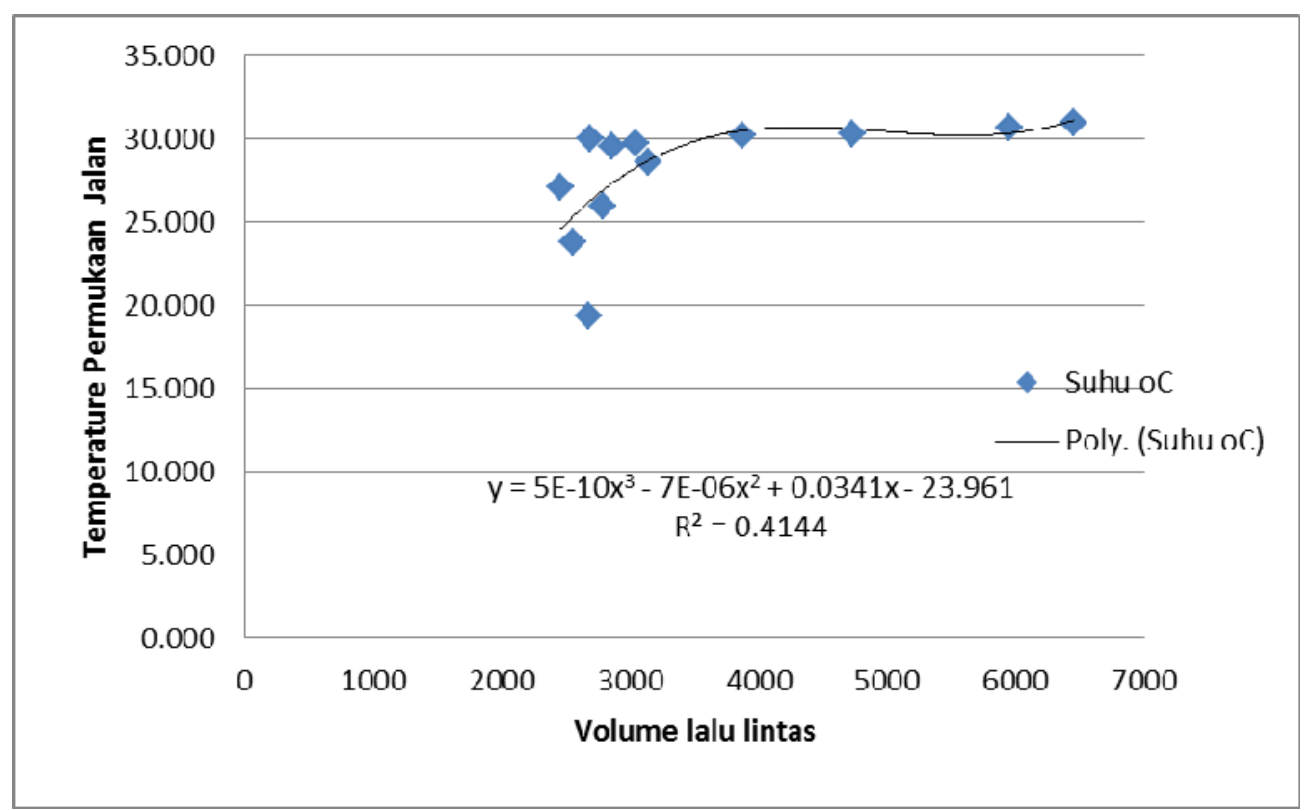

Gambar 16. Algoritma model polinom kubik volume lalu lintas

Dari algoritma penginderaan jauh untuk volume lalu lintas yang diberikan Gambar 12. hingga Gambar 17. Diperoleh gambaran bahwa polinomial kubik memiliki nilai $\mathrm{R}$ yang lebih besar dibandingkan dengan model lainnya, dimana untuk model polinomial kubik diperoleh persamaan $y=5 \mathrm{E}-10 \mathrm{x}^{3}-7 \mathrm{E}-06 \mathrm{x}^{2}+$ $0,0341 \mathrm{x}-23,961$ dengan nilai $\mathrm{R} 2=0,414$. Untuk hubungannya dengan suhu permukaan tanah berlaku persamaan dimodifikasi sebagai berikut :

$\mathrm{T}=5 \mathrm{E}-10 . \mathrm{V}^{3}-7 \mathrm{E}-06 \cdot \mathrm{V}^{2}+0,0341 . \mathrm{V}-23,961$, dimana $\mathrm{T}$ adalah suhu dan $\mathrm{V}$ adalah volume lalu lintas. 


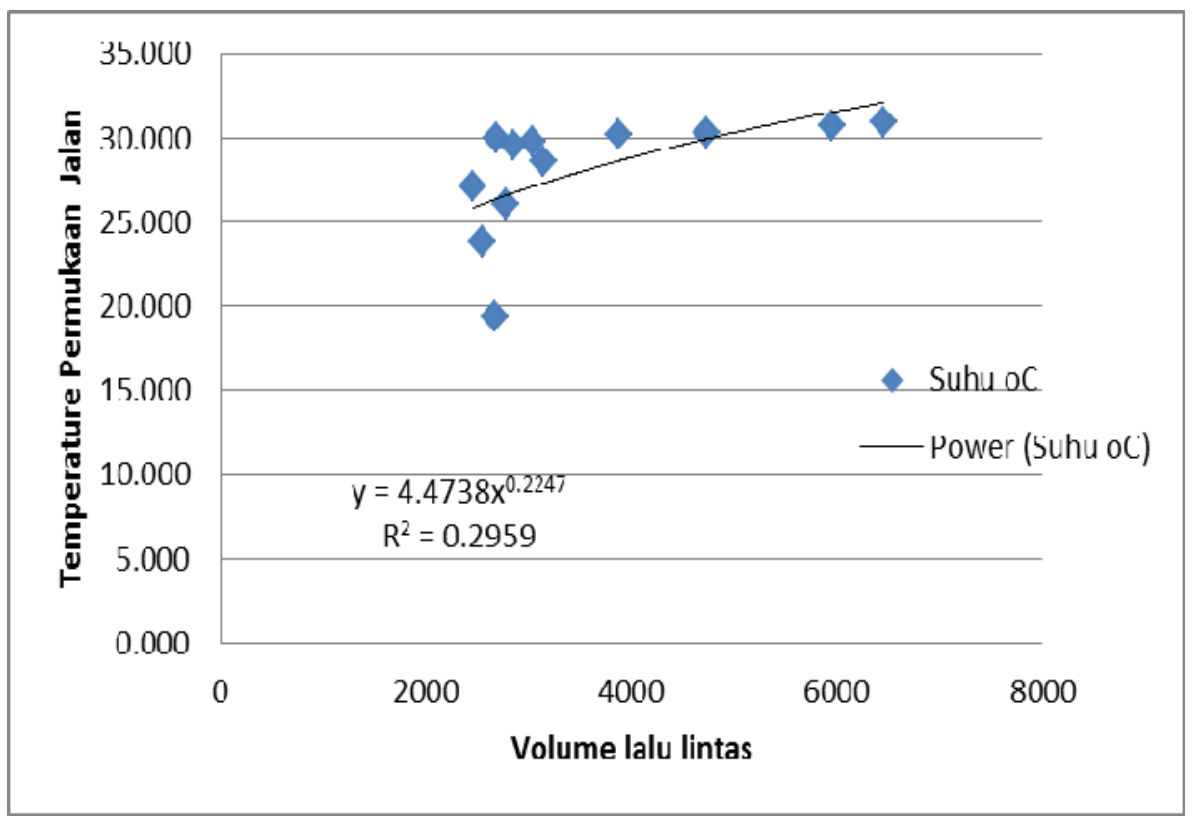

Gambar 17. Algoritma model power volume lalu lintas

Tabel 5 merupakan resume dari penggambaran grafik yang sudah diberikan sebelumnya dari Gambar 6 hingga gambar 11. Dan diperoleh model yang dapat memberikan gambaran korelasi antara kepadatan lalu lintas dengan suhu permukaan tanah yang didetaksi oleh citra satelit.

Tabel 6.merupakan resume dari penggambaran grafik untuk Gambar 12 hingga Gambar 17 yang menghasilkan nilai $\mathrm{R}$ yang terbesar ada pada model polinomial kubik dengan $\mathrm{R}$ sebesar 0,414

Tabel 5. Algoritma penginderaan jauh untuk kepadatan lalu lintas terhadap suhu permukaan tanah

\begin{tabular}{|c|c|c|c|}
\hline No & Algoritma & Model & $\mathbf{R}^{2}$ \\
\hline 1 & Linier & $\mathrm{y}=0,0387 \mathrm{x}+23,683$ & 0,309 \\
\hline 2 & Eksponensial & $\mathrm{y}=23,63 \mathrm{e}^{0,0014 \mathrm{x}}$ & 0,274 \\
\hline 3 & Logaritmik & $\mathrm{y}=5,4425 \ln (\mathrm{x})+2,7338$ & 0,364 \\
\hline 4 & Polinom kuadratik & $\mathrm{y}=-0,0006 \mathrm{x}^{2}+0,2074 \mathrm{x}+13,584$ & 0,416 \\
\hline 5 & Polinom kubik & $\mathrm{y}=1 \mathrm{E}-05 \mathrm{x}^{3}-0,0057 \mathrm{x}^{2}+0,8985 \mathrm{x}-15,255$ & 0,485 \\
\hline 6 & Power & $\mathrm{y}=10,755 \mathrm{x}^{0,2043}$ & 0,324 \\
\hline
\end{tabular}

Sumber : hasil perhitungan 
Tabel 6. Algoritma penginderaan jauh untuk volume lalu lintas terhadap suhu permukaan tanah

\begin{tabular}{|c|c|c|c|}
\hline No & Algoritma & Model & $\mathbf{R}^{\mathbf{2}}$ \\
\hline 1 & Linier & $\mathrm{y}=0,0014 \mathrm{x}+23,057$ & 0,299 \\
\hline 2 & Eksponensial & $\mathrm{y}=23,094 \mathrm{e}^{5 \mathrm{E}-05 \mathrm{x}}$ & 0,263 \\
\hline 3 & Logaritmik & $\mathrm{y}=6,0081 \ln (\mathrm{x})-20,826$ & 0,334 \\
\hline 4 & Polinom kuadratik & $\mathrm{y}=-8 \mathrm{E}-07 \mathrm{x}^{2}+0,0085 \mathrm{x}+9,3073$ & 0,387 \\
\hline 5 & Polinom kubik & $\mathrm{y}=5 \mathrm{E}-10 \mathrm{x}^{3}-7 \mathrm{E}-06 \mathrm{x}^{2}+0,0341 \mathrm{x}-23,961$ & 0,414 \\
\hline 6 & Power & $\mathrm{y}=4,4738 \mathrm{x}^{0,2247}$ & 0,296 \\
\hline
\end{tabular}

Sumber : hasil perhitungan

Dari Tabel 5. Dan Tabel 6. Dapat dilihat bahwa nilai R untuk masingmasing model yang ada pada perhitungan kepadatan arus lalu lintas maupun volume lalu lintas tidak ada yang melebihi 0,5 hal ini dapat terjadi karena pada saat citra satelit diambil oleh pesawat ruang angkasa pada jarak yang lebih dari 700 kilometer untuk satelit Landsat 8, maka gangguan selama proses perekaman gambar dan data menjadi besar, salah satunya adalah gangguan awan dan debu di atmosfer.

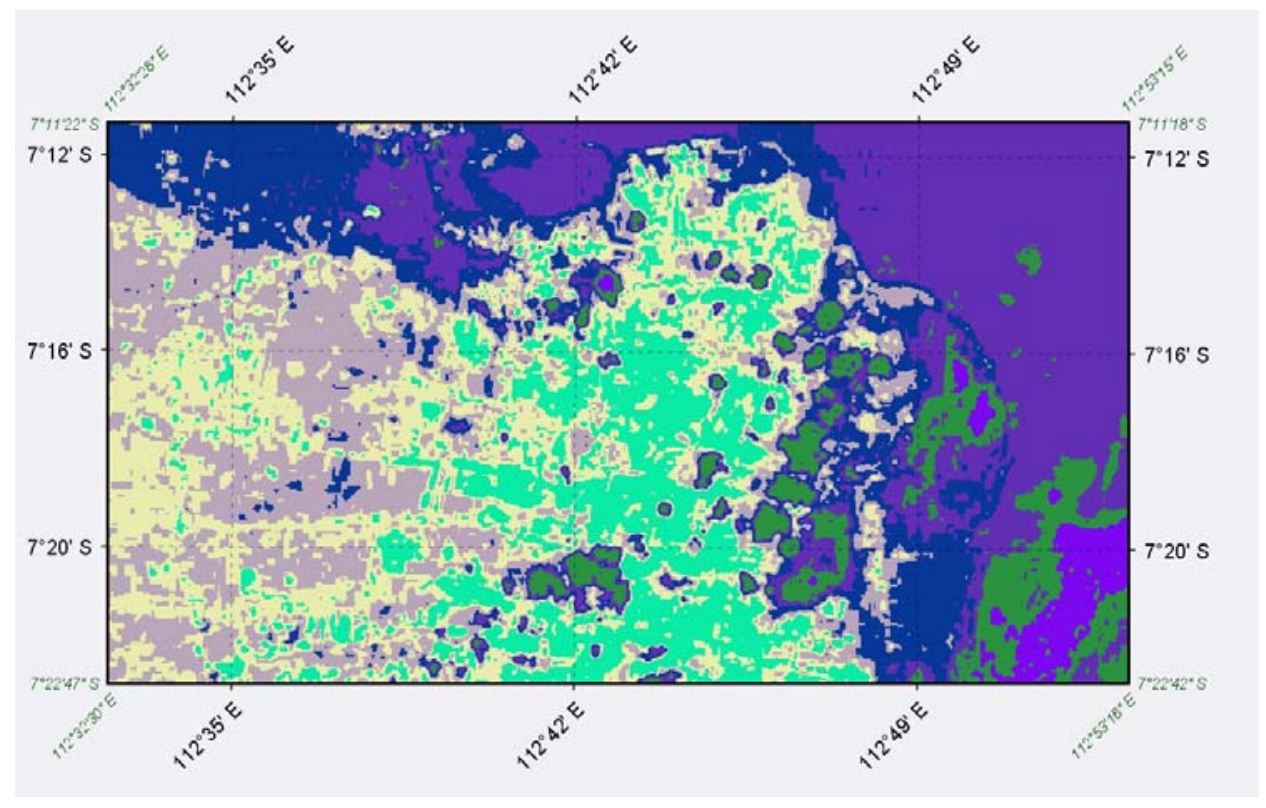

Deteksi Temperatur Permukaan Tanah Di Ruas Jalan Artery Dengan Citra Landsat 8 Dan 


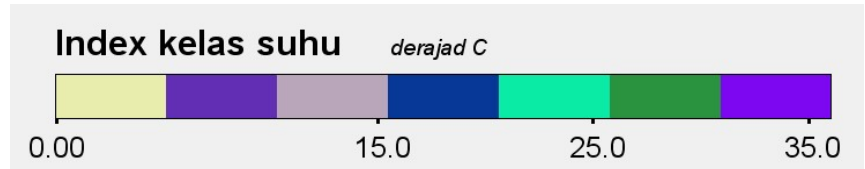

Gambar 18. Peta sebaran suhu permukaan tanah dari citra Landsat 8

\section{KESIMPULAN}

Algoritma penginderaan jauh dapat dikembangkan untuk mendeteksi hubungan antara suhu permukaan tanah dengan kepadatan arus lalu lintas juga volume lalu lintas.

Nilai korelasi yang dihasilkan bervariasi untuk masing-masing model yang dikembangkan dimana untuk kerapatan arus lalu lintas model polinomial kubik memiliki korelasi tersbesar dengan nilai $\mathrm{R}=485$, demikian juga untuk volume lalu lintas model polinomial kubik memiliki nilai korelasi yang terbesar dianatar yang lainnya dengan nilai $\mathrm{R}=414$.

Nilai R untuk kepadatan arus lalu lintas dan volume lalu lintas tidak terlalu signifikans, hal ini disebabkan saat perekaman data citra satelit mengalami banyak kendala selama perjalanannya ke muka bumi, sehingga banyak ditemui halangan pada pancaran gelombang elektromagnetik dari sinar matahari yang dipantulkan ke arah sensor pada citra satelit.

\section{SARAN}

Hasil penelitian ini bisa dikembangkan untuk jenis citra satelit yang lain terutama untuk citra satelit yang memiliki resolusi yang tinggi dan memiliki kanal untuk mendeteksi secara thermal penomena yang terjadi di permukaan bumi seperti suhu permukaan tanah.

Untuk kedepannya perlu dicari algoritma yang lain dengan penambahan variabel iklim dan kelembaban udara sehingga diharapkan panas permukaan bumi dapat dideteksi lewat kanal dari citra satelit dengan lebih akurat.

\section{UCAPAN TERIMA KASIH}

Penulis mengucapkan banyak terima kasih kepada Jurusan Teknik Sipil UPN Veteran Jatim yang sudah memberikan kemudahan dalam pemakaian laboratorium Sistem Informasi Geografis serta kepada mahasiswa teknik sipil UPN yang sudah bersedia menjadi surveyor lapangan. 


\section{REFERENSI}

1. Gillespie, A.; Rokugawa, S.; Matsunaga, T.; Cothern, J.S.; Hook, S.; Kahle, A.B. , (1998), A temperature and emissivity separation algorithm for Advanced Spaceborne Thermal Emission and Reflection Radiometer (ASTER) images. IEEE Trans. Geosci. Remote Sens. , 36, 1113-1126.

2. Hutengs, C.; Vohland, M. , (2016), Downscaling land surface temperatures at regional scales with random forest regression. Remote Sens. Environ. , 178, 127-141.

3. Li, Z.L.; Tang, H.; Wu, H.; Ren, H.; Yan, G.J.; Wan, Z.; Trigo, I.F.; Sobrino, J. , (2013), Satellite-derived land surface temperature: Current status and perspectives. Remote Sens. Environ. , 131, 14-37.

4. Liu, Y.; Hiyama, T.; Yamaguchi, Y. , (2006), Scaling of land surface temperature using satellite data: A case examination on ASTER and MODIS products over a heterogeneous terrain area. Remote Sens. Environ. , 105, 115-128.

5. Merlin, O.; Duchemin, B.; Hagolle, O.; Jacob, F.; Coudert, B.; Chehbouni, G.; Dedieu, G.; Garatuza, J.; Kerr, Y. ,(2010), Disaggregation of MODIS surface temperature over an agricultural area using a time series of Formosat-2 images. Remote Sens. Environ., 114, 2500-2512.

6. Pan, X.; Liu, Y.; Fan, X. , (2016), Satellite Retrieval of Surface Evapotranspiration with Nonparametric Approach: Accuracy Assessment over a Semiarid Region. Adv. Meteorol. , 2016, 1584316.

7. Qu, J.J.; Hao, X.; Kafatos, M.; Wang, L. , (2006), Asian dust storm monitoring combining Terra and Aqua MODIS SRB measurements. IEEE Geosci. Remote Sens. Lett. , 3, 484-486.

8. Sandholt, I.; Rasmussen, K.; Andersen, J., (2002), A simple interpretation of the surface temperature/vegetation index space for assessment of surface moisture status. Remote Sens. Environ. , 79, 213-224.

9. Sandholt, I.; Nielsen, C.; Stisen, S., (2009), A Simple Downscaling Algorithm for Remotely Sensed Land Surface Temperature; American Geophysical Union: Washington, DC, USA, .

10. Tang, H.; Bi, Y.; Li, Z.L.; Xia, J., (2008), Generalized split-window algorithm for estimate of land surface temperature from Chinese geostationary FengYun meteorological satellite (Fy-2C) data. Sensors, 8, 933-951.

11. Wan, Z.; Dozier, J. ,(1996), Generalized split-window algorithm for retrieving land-surface temperature from space. IEEE Trans. Geosci. Remote Sens. , 34, 892-905.

12. Yang, Y.; Li, X.; Pan, X.; Zhang, Y.; Cao, C. , (2017), Downscaling Land Surface Temperature in Complex Regions by Using Multiple Scale Factors with Adaptive Thresholds. Sensors , 17, 744.

13. Yang, G.; Pu, R.; Zhao, C.; Huang, W.; Wang, J. , (2011), Estimation of subpixel land surface temperature using an endmember index based technique: A case examination on ASTER and MODIS temperature products over a heterogeneous area. Remote Sens. Environ., 115, 12021219. 
14. Zakšek, K.; Oštir, K. , (2012), Downscaling land surface temperature for urban heat island diurnal cycle analysis. Remote Sens. Environ. , 117, 114 124.

15. Zhou, J.; Li, J.; Zhang, L.; Hu, D.; Zhan, W. , (2012), Intercomparison of methods for estimating land surface temperature from a Landsat-5 TM image in an arid region with low water vapour in the atmosphere. Int. J. Remote Sens. , 33, 2582-2602. 